\title{
Biogeochemistry of $\mathrm{N}, \mathrm{P}$ and $\mathrm{Si}$ in Baltic Sea sediments: response to a simulated deposition of a spring diatom bloom
}

\author{
Daniel J. Conley ${ }^{1, *}$, Ronald W. Johnstone ${ }^{2}$
}

\begin{abstract}
${ }^{1}$ Horn Point Environmental Laboratory, Center for Environmental and Estuarine Studies, University of Maryland System, PO Box 775, Cambridge, Maryland 21613, USA and Department of Systems Ecology, Stockholm University, S-106 91 Stockholm, Sweden

${ }^{2}$ Aquatic Ecology, Zoology Institution, Stockholm University, S-106 91 Stockholm, Sweden
\end{abstract}

\begin{abstract}
Experimental studies of intact cores from the Baltic Sea were conducted to determine the response of sediment nutrient recycling processes to varied inputs of organic matter. A 2 mo enrichment experiment was carried out in the laboratory on sediment cores held at $4^{\circ} \mathrm{C}$ using a flow-through system where overlying waters were continuously replaced at a rate of $1 \mathrm{~d}^{-1}$ The experiments were designed to simulate the deposition of organic matter that occurs during a typical spring diatom bloom ( $1 x$ ) and under enriched conditions with eutrophication at approximately 3 times $(3 \times)$ a normal spring bloom utilizing added organic matter from a natural phytoplankton assemblage collected in a eutrophic coastal fjord during the spring diatom bloom. Low and constant sediment-water fluxes wer observed throughout the duration of the experiment in control cores with no added organic matter. In all cases an immediate response was noted when a single pulsed addition of algal material was added to the sediment surface. Sediment-water fluxes of ammonium $\left(\mathrm{NH}_{4}{ }^{+}\right)$, and dissolved inorganic phosphate (DIP) increased significantly (ANOVA, $\mathrm{p}<0.01$ ). For nitrite + nitrate $\left(\mathrm{NO}_{2}{ }^{-}+\mathrm{NO}_{3}{ }^{-}\right.$) and dissolved silicate (DSi) sediment-water fluxes, differences were initially observed; however, only the $\mathrm{NO}_{2}{ }^{-}+\mathrm{NO}_{3}{ }^{-}$fluxes were significantly different over time (ANOVA, $\mathrm{p}<0.01$ ). Fluxes of $\mathrm{NO}_{2}{ }^{-}+\mathrm{NO}_{3}{ }^{-}$were into the sediment for 3 to $10 \mathrm{~d}$ after addition of organic material, followed by small fluxes out of the sediment. The addition of algal material proportionate to a normal spring bloom $(1 \times)$ had only a minor effect on porewater nutrient concentrations, whereas the $3 x$ treatment substantially modified both the short- and long-term response of sediments. A greater proportion of anaerobic decomposition products, e.g. $\mathrm{NH}_{4}{ }^{+}$and $\mathrm{DIP}$, were observed with an expansion of more reducing conditions resulting from the addition of organic matter. The percentage of Si remineralized decreased as the flux of material to the sediment increased. Deposition rates similar to a typical spring bloom did not have long-term effects on the nutrient recycling processes; however, increases in the present level of deposition (as simulated in this study), which are forecasted with further eutrophication in the Baltic Sea, may have a significant impact on nutrient biogeochemical cycles.
\end{abstract}

\section{INTRODUCTION}

Large and intense spring blooms are often found in regions characterized by marked seasonality such as in northern temperate latitudes. The mechanisms associated with the formation of these blooms include

\footnotetext{
- Present address: National Environmental Research Institute, Frederiksborgvej 399, PO Box 358, DK-4000 Roskilde, Denmark
}

water column stability, periods of rapidly increasing incident solar radiation and low grazing pressure (Smetacek \& Passow 1989). These blooms can form, grow and senesce in as little as 1 to $2 \mathrm{wk}$ (Smetacek et al. 1978) and large variations can occur in their timing (Smetacek 1985). The particles produced in the water column during the spring bloom have a high nutritional content and, after settling, can form the bulk of the annual food supply to the benthos (Gardner et al. 1985). 
In addition to the character of the material settling out from the water column, one of the most important factors controlling the processes responsible for the remineralization of organic matter and nutrient recycling is the actual amount of organic material and the time frame over which it is delivered to the benthos. Pulsed inputs of organic material can have a profound impact not only on sediment-water fluxes (Kelly \& Nixon 1984, this study), but also on the benthos (Cederwall \& Elmgren 1980), underlying sediment chemistry (Graf et al. 1984), may increase microbial activity (Graf 1987), and modify the preservation of organic matter in sediments (Jonsson et al. 1990). Reports suggest that peaks in sediment microbial activity and denitrification follow pulsed inputs of organic matter with deposition of the spring diatom bloom (Jensen et al. 1990, Caffrey et al. 1993).

Given the significance that benthic nutrient dynamics and sediment biogeochemical processes can have for marine ecosystems, any attempt to assess or model the nutrient dynamics of marine ecosystems must include an examination of this aspect. Ongoing studies in the Baltic Sea are good examples of this. The Baltic Sea receives significant anthropogenic nutrient inputs (Wulff et al. 1990) and has, in recent years, exhibited phenomena characteristic of a eutrophic ecosystem (Wulff et al. 1986, Elmgren 1989). It is among one of the most studied marine areas of the world, yet, until recently, there were surprisingly few direct measurements of the biogeochemical processes which drive the system. Both mass balance calculations (e.g. Larsson et al. 1985) and simulation models (e.g. Stigebrandt \& Wulff 1987) for the Baltic Sea have highlighted the potential role of sediments as a major nutrient sink. This role has been verified to an extent for phosphorus (Carman \& Wulff 1989); however, it would seem from more recent work (Johnstone \& Koop unpubl. data) that the predictive accuracy of these models needs refining and that sediment responses may be considerably different over time than expected.

The present investigation focuses on an experimental simulation of the deposition of a spring bloom using natural samples of phytoplankton. In order to further our understanding of eutrophication of coastal waters and its impact on hypoxic and anoxic events in the Baltic Sea, our objectives were to measure the effect of supplemented organic matter on biogeochemical cycling and nutrient processes in Baltic Sea sediments. Specifically, we aimed to characterize the changes in sediment nutrient chemistry, to quantify the fluxes of N, P and Si, and to assess the duration of these changes over time so that we could determine the changes that may occur in remineralization with projected increases in organic matter deposition.

\section{MATERIALS AND METHODS}

Study area. The investigation was carried out in the Baltic Sea off of the Stockholm Archipelago, Sweden. An $82 \mathrm{~m}$ deep site $\left(58^{\circ} 31^{\prime} 19^{\prime \prime} \mathrm{N}\right.$ and $18^{\circ} 02^{\prime} 60^{\prime \prime} \mathrm{E}$, Koop et al. 1990) was chosen for study. This area experiences periods of seasonal hypoxia and anoxia with a poorly developed infaunal population. Salinity and temperature at the time of collection were $12 \%$ and $4^{\circ} \mathrm{C}$ respectively. Bottom waters contained approximately $4 \mathrm{mg} \mathrm{l}^{-1}$ of dissolved $\mathrm{O}_{2}$.

Sampling. Sediment cores were collected aboard the RV 'Aurelia' using a modified Kajak corer (Blomqvist \& Abrahamsson 1985) equipped with an acrylic liner $8 \mathrm{~cm}$ in diameter and $50 \mathrm{~cm}$ in length. Cores were collected in mid-March prior to the beginning of the spring diatom bloom and transported back to the Askö Laboratory in insulated containers. Near-bottom water was also collected several times at the sampling site for use in the flow-through system described below. Cores were maintained in the laboratory for approximately $3 \mathrm{wk}$ prior to the supplemental addition of organic matter to cores.

Experimental design. Sediment cores containing $20 \mathrm{~cm}$ sediment with $20 \mathrm{~cm}$ of overlying water (ca 1 l) were subjected to 3 different treatments. These included cores $(n=5)$ with no added algal material (control), cores ( $n=4$ ) with algal material added in approximately spring bloom proportions $(1 \times)$, and cores $(n=4)$ with algal material added at 3 times spring bloom proportions $(3 \times)$. In addition, cores without sediments (NoSed) were incubated containing bottom water only ( $n=2$ ), cores containing bottom water then treated with algal additions at $1 \times(n=2)$ and $3 \times(n=2)$ proportions; these cores were sampled in parallel with cores containing sediment.

Algal material was collected in situ by continuous centrifugation using an Alfa-Laval Centrifuge (Model No. LAPX202) aboard the RV 'Aurelia' in the Himmerfjärden coastal estuary. Water was pumped from the chlorophyll maximum at $10 \mathrm{~m}$ depth during the spring diatom bloom and passed through the centrifuge at a rate of $600 \mathrm{I} \mathrm{h}^{-1}$. The algal material was removed from the centrifuge at intervals of $2 \mathrm{~h}$. The total algal material thus collected was stored for $3 \mathrm{~d}$, gently washed with seawater to remove much of the rapidly degradable leachates. The material was added in a single pulse by gently applying the material to the surface of cores using a T-fitting on a $50 \mathrm{ml}$ syringe. The material was allowed to settle to the sediment surface for a period of $6 \mathrm{~h}$ before the flow-through water system and the bubbling system were re-established.

Flux measurements. Cores were maintained in a water bath in the dark at $4^{\circ} \mathrm{C}$ for the duration of the experiment. When flux measurements were not being made, the water overlying the cores was continuously 
replaced approximately once a day with bottom water collected from the sampling site using a peristaltic pump equipped with multiple pump heads. Circulation of the overlying water within the cores was maintained by gentle bubbling with filtered air; this treatment also maintained dissolved $\mathrm{O}_{2}$ concentrations in the overlying waters greater than $5 \mathrm{mg} \mathrm{l}^{-1}$ Three sedimentwater flux measurements were made prior to addition of added organic matter to ensure consistent fluxes were measured between cores, and 8 flux measurements were completed after addition of added organic material. Measurement of fluxes were made $2 \mathrm{~d}$ apart early in the experiment and the time between flux measurements was increased with the length of the experiment. The flow of water was stopped for flux measurements with 4 water samples $(25 \mathrm{ml}+10 \mathrm{ml}$ wash) removed over a 6 to $12 \mathrm{~h}$ period; the period varied depending upon the time needed to measure a significant flux. Water samples were immediately filtered through Whatman GF/F 25 mm filters. Syringes and filter holders used in the filtration were acidwashed, then rinsed with the sample prior to filtration.

Porewater nutrients. Sediment cores were sacrificed twice during the experiment and analyzed for porewater nutrient concentrations. Three treatment cores (control, $1 \times$ and $3 \times$ ) were sacrificed approximately 1 wk after the algal additions (Day 8), and again at the termination of the experiment (Day 27). Sediment cores were sectioned at in situ temperatures in a glove bag under a $\mathrm{N}_{2}$ atmosphere. Sediment sections were mixed well and transferred to $50 \mathrm{ml}$ acid-washed centrifuge tubes. Sediments were sectioned at $0.5 \mathrm{~cm}$ intervals in the upper $2 \mathrm{~cm}$, at $1 \mathrm{~cm}$ intervals to $5 \mathrm{~cm}$, and $3 \mathrm{~cm}$ intervals thereafter. Porewaters from 1 set of samples were immediately extracted by centrifugation, filtered through $0.4 \mu \mathrm{m}$ Millipore cellulose acetate filters and analyzed for nutrient concentrations as described for flux measurements.

Analytical determinations. Total sediment carbon and total sediment nitrogen were determined by high temperature combustion (Control Equipment Elemental Analyzer), sediment biogenic silica (BSi) by extraction with $1 \% \mathrm{Na}_{2} \mathrm{CO}_{3}$ (DeMaster 1981), and total phosphorus (TP) and organic phosphorus (Org-P) by extraction with $1 \mathrm{M} \mathrm{HCl}$ before and after combustion (Aspila et al. 1976). Ammonium $\left(\mathrm{NH}_{4}{ }^{+}\right.$) concentration in water samples collected from core incubations and porewaters were immediately determined using the indophenol blue method (Parsons et al. 1984). Samples for dissolved silicate (DSi) were refrigerated and analysed by reduction of silicomolybdate with ascorbic acid (Parsons et al. 1984). Samples for nitrite + nitrate $\left(\mathrm{NO}_{2}{ }^{-}+\mathrm{NO}_{3}{ }^{-}\right)$and dissolved inorganic phosphate (DIP) were immediately frozen for later analysis. After thawing, samples were analyzed for $\mathrm{NO}_{2}^{-}+\mathrm{NO}_{3}^{-}$by cad- mium reduction (Parsons et al. 1984) and for DIP by molybdenum blue (Parsons et al. 1984). Chemical characterization of added algal material was accomplished by high temperature combustion for total carbon (TC) and total nitrogen (TN), for BSi by extraction with $0.2 \mathrm{M} \mathrm{NaOH}$ (Paasche 1980), and for TP by digestion in acid persulfate (Koroleff 1976).

\section{RESULTS}

\section{Sediment cores}

Despite the existence of limited numbers of fauna in the upper $3 \mathrm{~cm}$ of sediment (E. Olafsson unpubl. data), cores left to dry showed distinct laminations of varied thickness. Microscopic examination showed no apparent differences in composition of sediment between varves. It should also be noted here that in the control and $1 \times$ cores the infauna appeared to be healthy at the end of the experiment; however, in the $3 \times$ cores some dead animals were observed on the sediment surface. This did not correlate with the observed nutrient fluxes. The upper $3 \mathrm{~cm}$ of sediment, representing the last ca 40 years of sedimentation as determined by ${ }^{210} \mathrm{~Pb}$ geochronology (sedimentation rate of $84 \mathrm{mg}$ $\mathrm{cm}^{-2} \mathrm{yr}^{-1} ; \mathrm{J}$. C. Cornwell unpubl, data), contain significantly higher concentrations of TC (4.66 wt \%), TN $(0.56 \mathrm{wt} \%)$, TP $(0.134 \mathrm{wt} \%)$, Org-P $(0.055 \mathrm{wt} \%)$ and BSi (4.32 wt $\%$ as $\mathrm{SiO}_{2}$ ) than do sediments below $5 \mathrm{~cm}$ (deposited before ca 1920), with sediments containing several times less TC $(2.32 \mathrm{wt} \%)$, TN $(0.24 \mathrm{wt} \%)$, TP $(0.068 w t \%)$, Org-P $(0.013 w t \%)$ and BSi $(1.31 w t \%$ as $\mathrm{SiO}_{2}$ ) than in the upper sediments. Sediment porosity ranged from 0.86 to 0.90 in surficial sediments $(0$ to $4 \mathrm{~cm}$ ) and porosity declined to ca 0.80 deeper in the cores $(11$ to $14 \mathrm{~cm}$ ). At the end of the experiment sediment cores in the $3 \times$ treatment had growth of Beggiatoa sp. bacteria at the sediment-water interface despite the fact that overlying waters were oxygenated throughout the duration of the experiment.

\section{Characterization of added algal material}

Supplemented algal carbon added to cores in the $1 \times$ treatment (6.9 $\mathrm{g} \mathrm{C} \mathrm{m}^{-2}$ ) were in approximate spring bloom proportions (Table 1). Larsson et al. (1986) determined that the amount of carbon sedimented during the spring diatom bloom near our study site was approximately $5 \mathrm{~g} \mathrm{C} \mathrm{m}^{-2}$. Other estimates from the Baltic Sea of the amount of organic material typically sedimenting during the spring diatom bloom range from as much as $47 \mathrm{~g} \mathrm{C} \mathrm{m}^{-2}$ averaged over the entire Baltic Sea (Elmgren 1984), $33 \mathrm{~g} \mathrm{C} \mathrm{m}^{-2}$ off of southwest 
Table 1. Nutrient composition $\left(\mathrm{g} \mathrm{m}^{-2}\right)$ of algal material added to cores. TC: total carbon; BSi: biogenic silica; TN: total nitrogen; TP: total phosphorus; $1 x$ : added at approximately spring bloom proportions; $3 \times$ : added at $3 \times$ spring bloom proportions

\begin{tabular}{|ccccc|}
\hline Treatment & TC & BSi & TN & TP \\
\hline $1 \times$ & 6.91 & 4.35 & 1.11 & 0.20 \\
$3 \times$ & 20.4 & 13.2 & 3.27 & 0.59 \\
\hline
\end{tabular}

Finland (Lignell et al. 1993), 20 to $50 \mathrm{~g} \mathrm{C} \mathrm{m}^{-2}$ in the Kattegat (Floderus \& Håkanson 1989, Rydberg et al. 1990) and $10 \mathrm{~g} \mathrm{C} \mathrm{m}^{-2}$ in Kiel Bight (Graf et al. 1982). The composition of added algal material was relatively phosphorus rich with a molar ratio of $88: 12: 11: 1$ as $C: N: S i: P$. The C:N ratio was 7.2 and the N:Si ratio was 1.1:1 indicating that the added algal material was similar in composition to healthy exponentially growing diatoms (Brzezinski 1985).

\section{Porewater profiles}

For the most part distributions of porewater nutrient concentrations in control cores, e.g. those incubated for the duration of the experiment with no added algal material, remained constant (Figs. 1 to 4 ). Addition of

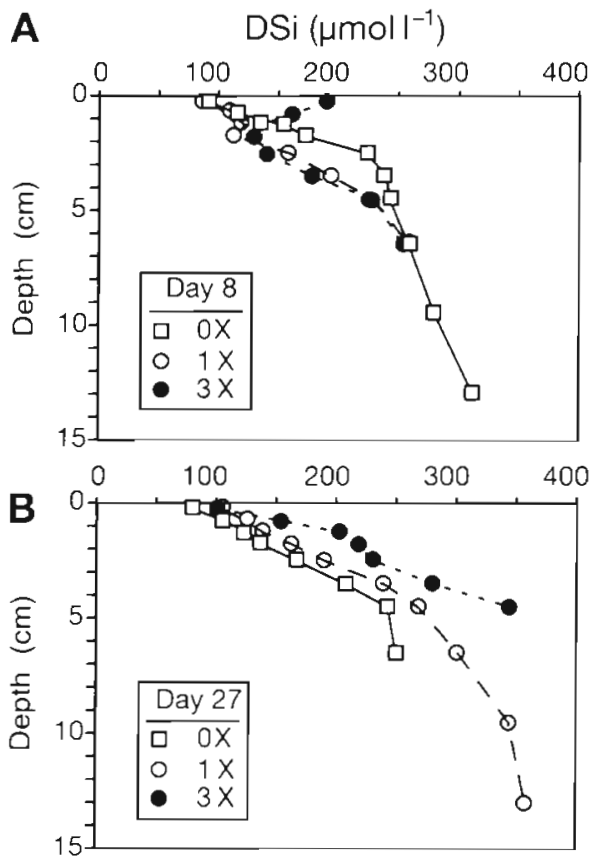

Fig. 1. Porewater dissolved silicate (DSi) concentration. Cores sectioned (A) on Day 8 after the addition of algal material and (B) at the termination of the experiment (Day 27). 0x: control, no added algal material; $1 x$ : algal material in approximately spring bloom proportions; $3 \times$ : algal material added at $3 \times$ spring bloom proportions

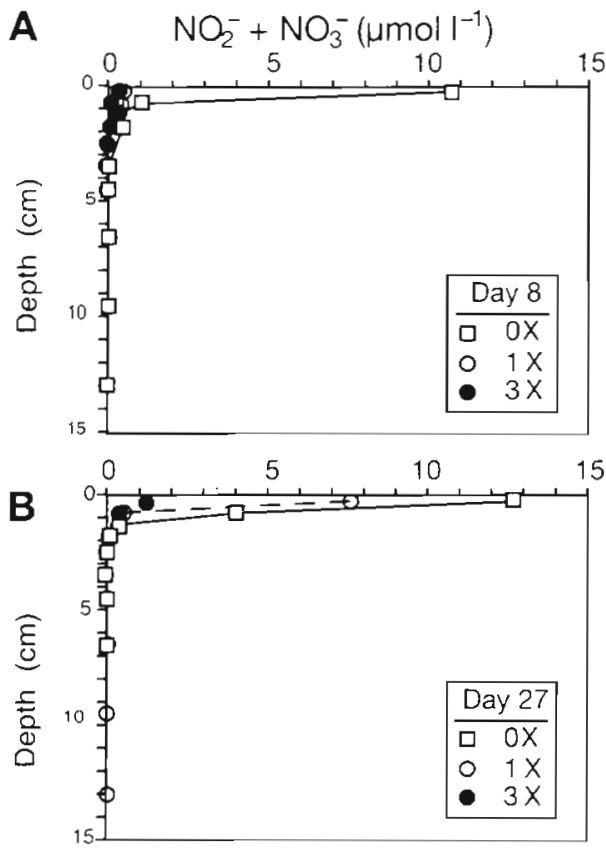

Fig. 2. Porewater nitrate $\left(\mathrm{NO}_{2}{ }^{-}+\mathrm{NO}_{3}^{-}\right)$concentration. Cores sectioned (A) on Day 8 after the addition of algal material and (B) at the termination of the experiment (Day 27). Symbols as in Fig. 1

A $\mathrm{NH}_{4}^{+}\left(\mu \mathrm{mol} \mathrm{I}^{-1}\right)$
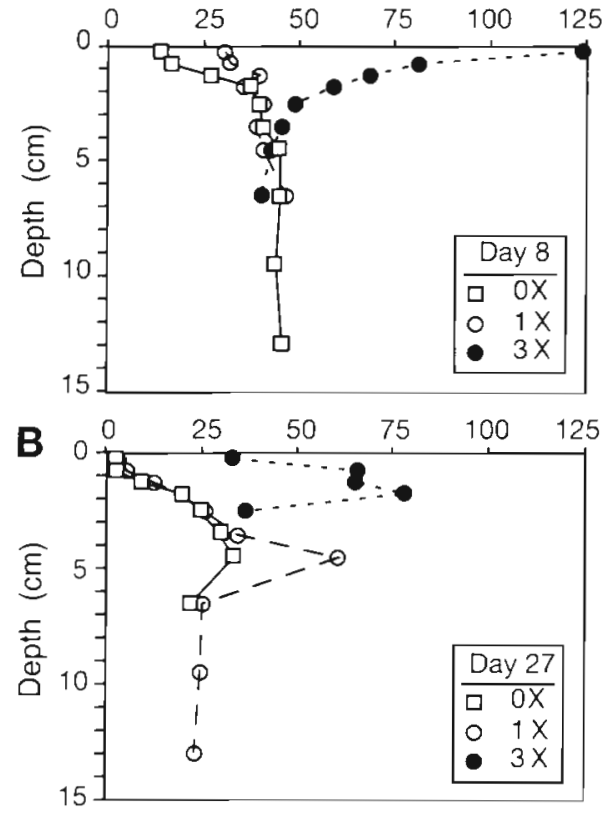

Fig. 3. Porewater ammonium $\left(\mathrm{NH}_{4}{ }^{+}\right)$concentration. Cores sectioned (A) on Day 8 after the addition of algal material and (B) at the termination of the experiment (Day 27). Symbols as in Fig. 1 


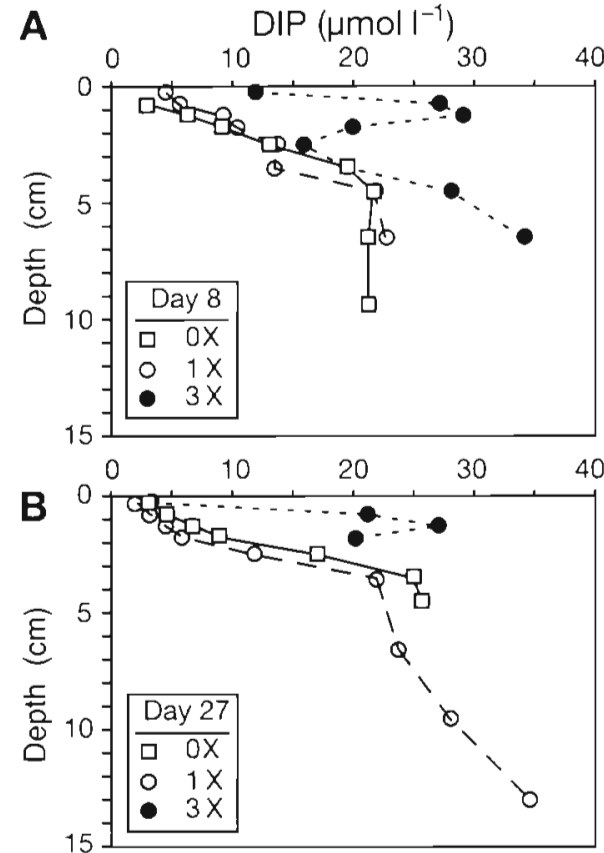

Fig. 4. Porewater dissolved inorganic phosphate (DIP) concentration. Cores sectioned (A) on Day 8 after the addition of algal material and $(B)$ at the termination of the experiment (Day 27). Symbols as in Fig. 1

algal material to the sediment-water interface had a negligible to transient impact on the distribution of porewater nutrient concentrations with the $1 \times$ treatment, whereas distributions of porewater nutrient concentrations were greatly modified in the $3 \times$ treatment. and, in some cases, altered porewater nutrient distributions throughout the duration of the experiment.

Addition of algal material in the $1 \times$ treatment had no distinguishable influence on porewater DSi concentrations (Fig. 1A, B). A near-surface increase in DSi was observed for the $3 \times$ treatment after 1 wh with higher concentrations in the 0 to $1.5 \mathrm{~cm}$ interval and concentrations downcore similar to those observed in other cores. At the termination of the experiment a typical exponential gradient in DSi concentrations had been re-established in the $3 \times$ treatment; though concentrations were higher, they were not greatly different from those observed in the control cores.

In all cores $\mathrm{NO}_{2}{ }^{-}+\mathrm{NO}_{3}{ }^{-}$concentrations below $1 \mathrm{~cm}$ in depth were always l'ess than $1 \mu \mathrm{moll}^{-1}$ with $\mathrm{NO}_{2}{ }^{-}+\mathrm{NO}_{3}{ }^{-}$ never penetrating deeper than $3 \mathrm{~cm}$ into the sediment (Fig. 2A, B). The addition of algal material in both the $1 \times$ and $3 \times$ treatments reduced porewater $\mathrm{NO}_{2}{ }^{-}+\mathrm{NO}_{3}{ }^{-}$concentrations to near undetectable concentrations after the 1 wk sampling. After $27 \mathrm{~d}$ of incubation porewater $\mathrm{NO}_{2}{ }^{-}$ $+\mathrm{NO}_{3}{ }^{-}$concentrations in the $1 \times$ treatment were approaching those observed in the control cores; in the $3 x$ treatment $\mathrm{NO}_{2}{ }^{-}+\mathrm{NO}_{3}{ }^{-}$concentrations were still considerably depressed from those observed in control cores.
Concentrations of $\mathrm{NH}_{4}^{+}$in porewaters were the most variable of the nutrients between samplings (Fig. 3A, B). Addition of algal material in the $1 \times$ treatment increased porewater $\mathrm{NH}_{4}{ }^{+}$concentrations during the 1 wk sampling only, and by the final sampling concentrations were indistinguishable from concentrations in control cores. The $3 \times$ treatment greatly modified porewater $\mathrm{NH}_{4}{ }^{+}$concentrations. At the $1 \mathrm{wk}$ sampling the highest $\mathrm{NH}_{4}{ }^{+}$concentrations were observed at the sediment-water interface with an exponential decrease with depth. At the end of the incubation a sub-surface maxima in $\mathrm{NH}_{4}{ }^{+}$concentrations was observed in the $3 \times$ treatment.

Porewater DIP concentrations were also generally unaffected by the addition of algal material to the sediment-water interface in the $1 \times$ treatment (Fig. 4A, B). By contrast, a large and distinct sub-surface maxima in DIP concentrations was observed in the $3 \times$ treatment at 1 to $2 \mathrm{~cm}$ for both post-addition samplings.

\section{Sediment-water fluxes}

Sediment-water fluxes of control cores remained relatively stable throughout the duration of the experiment (Figs. 5 to 8 ). In all cases dramatic changes occurred in sediment-water fluxes following the addi-

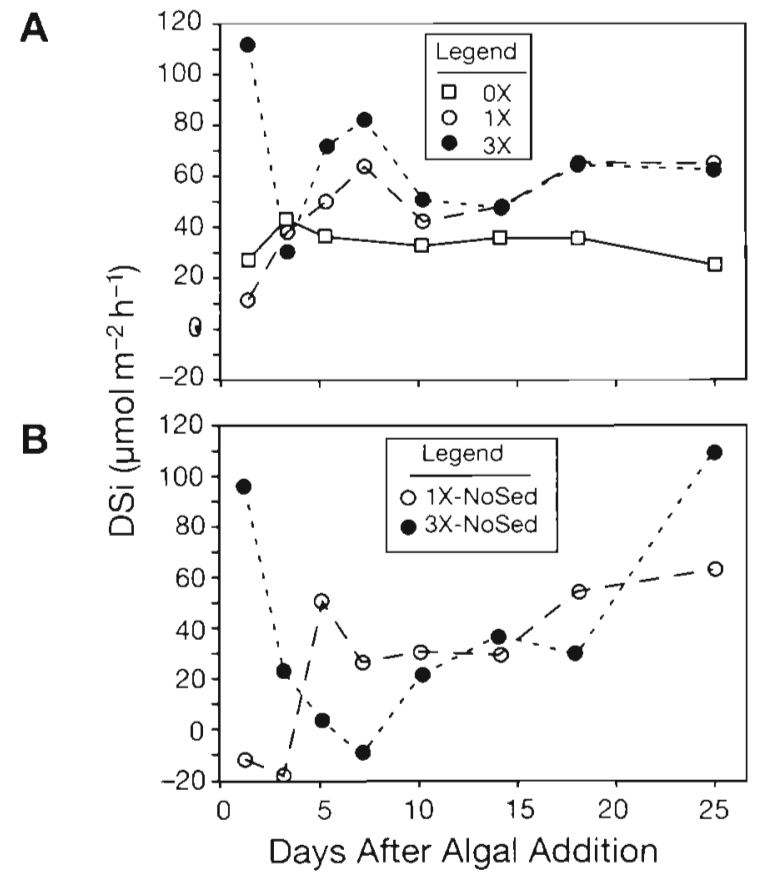

Fig. 5. Mean dissolved silicate (DSi) flux for (A) cores containing sediment and (B) cores containing no sediment (NoSed). 0x: control, no added algal material; $1 \times$ : algal material in approximately spring bloom proportions; $3 \times$ : algal material added at $3 \times$ spring bloom proportions 
A

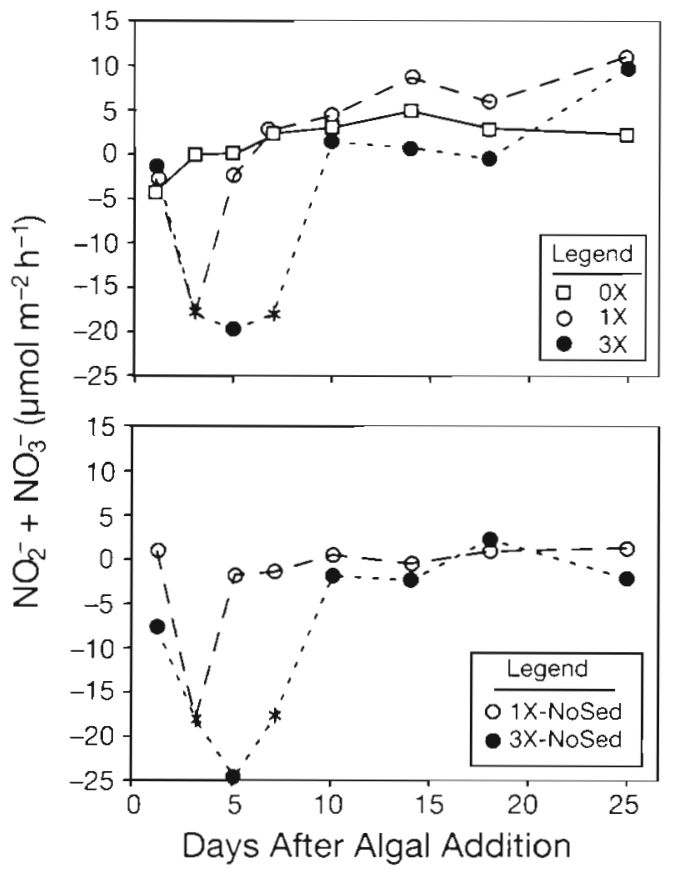

Fig. 6. Mean nitrite + nitrate $\left(\mathrm{NO}_{2}{ }^{-}+\mathrm{NO}_{3}{ }^{-}\right)$flux for (A) cores containing sediment and (B) cores containing no sediment (NoSed). (*) Minimum estimated nitrate flux into the sediment calculated by assuming that the sediment-water flux was equivalent to the rate of input of $\mathrm{NO}_{2}{ }^{-}+\mathrm{NO}_{3}{ }^{-}$brought into the cores via the flow-through system. Other symbols as in Fig. 5

tion of algal material to the sediment surface. A bimodal pattern was observed for DIP and $\mathrm{NH}_{4}{ }^{+}$fluxes, with fluxes increasing rapidly soon after addition of the algal material, a sharp decline $5 \mathrm{~d}$ post-addition, and a secondary peak 7 d post-addition. Significantly larger fluxes were observed for DIP and $\mathrm{NH}_{4}{ }^{+}$in the $3 \times$ treatment than in the $1 \times$ treatment (ANOVA; $F=3.51, \mathrm{df}=$ $2,54, \mathrm{p}=0.036$ and $F=56.76, \mathrm{df}=2,54, \mathrm{p}=0.0001$ respectively). For $\mathrm{NO}_{2}{ }^{-}+\mathrm{NO}_{3}{ }^{-}$and DSi fluxes, differences were initially observed, however, only the $\mathrm{NO}_{2}{ }^{-}$ $+\mathrm{NO}_{3}{ }^{-}$fluxes were significantly different (ANOVA; $F=6.52, \mathrm{df}=2,54, \mathrm{p}=0.003$ ). After only $1 \mathrm{wk}$ both of these fluxes in the $1 \times$ and $3 \times$ treatments were similar. Mean DSi fluxes in the algal treatments remained consistently higher than fluxes observed in control cores, but no significant differences were found under ANOVA $(F=1.34, \mathrm{df}=2,54, \mathrm{p}=0.27)$. Fluxes of $\mathrm{NO}_{2}{ }^{+}$ $\mathrm{NO}_{3}{ }^{-}$in the $3 \times$ treatment were into the sediment for a longer period of time than in the $1 \times$ treatment. It should be noted that we were not able to directly measure $\mathrm{NO}_{2}{ }^{-}+\mathrm{NO}_{3}{ }^{-}$fluxes in several instances because $\mathrm{NO}_{2}{ }^{-}+$ $\mathrm{NO}_{3}{ }^{-}$was completely removed from overlying waters. In these cases, a minimum $\mathrm{NO}_{2}^{-}+\mathrm{NO}_{3}^{-}$flux into the sediment was calculated by assuming that the sediment-water flux was equivalent to the rate of input of

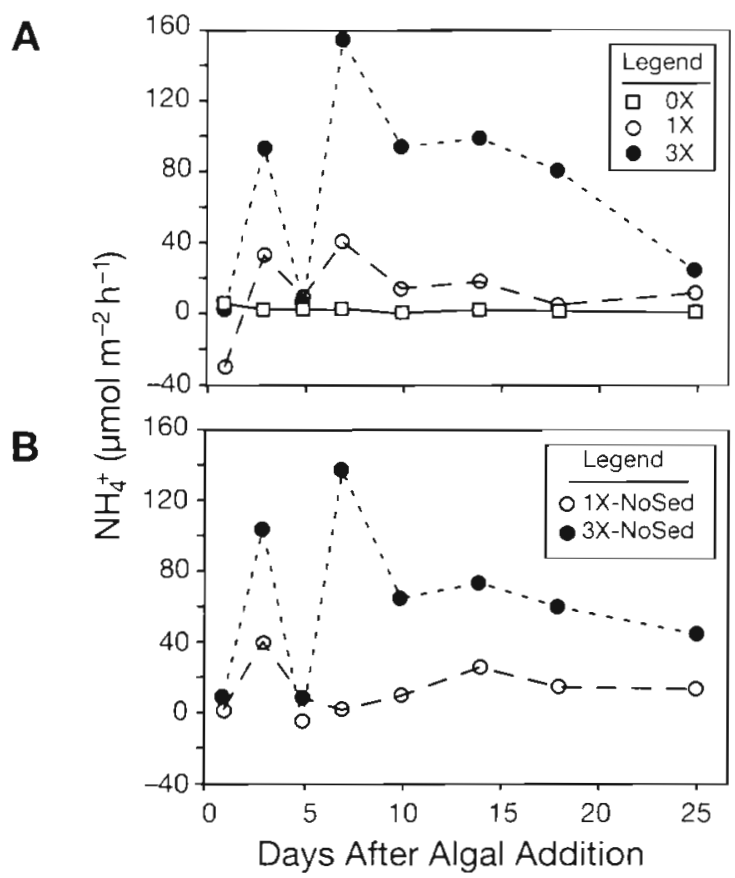

Fig. 7. Mean ammonium $\left(\mathrm{NH}_{4}{ }^{+}\right)$flux for (A) cores containing sediment and (B) cores containing no sediment (NoSed). Symbols as in Fig. 5

$\mathrm{NO}_{2}^{-}+\mathrm{NO}_{3}^{-}$brought into the cores via the flowthrough system $\left(1 \mathrm{~d}^{-1}\right)$ prior to the start of the incubation for a flux measurement.

In cores without sediments the remineralization of added algal material proceeded at rates somewhat less than those observed for cores with sediments (Figs. 5B to $8 \mathrm{~B}$ ), although similar patterns in nutrient remineralization were observed. Because of the small number of cores incubated without sediments $(n=2)$, analysis of variance with time and treatment could not be performed on these cores. Some uptake of nutrients by the algal material was initially observed following the single pulsed addition into cores without sediments, but this was short lived.

\section{Remineralization of added algal material}

An estimate of the percentage of added algal material remineralized over the course of the experiment can be made by trapezoidal integration of sedimentwater fluxes over the $27 \mathrm{~d}$ of incubation following the addition of organic matter. The percentage of added algal material remineralized relative to the amount added in the beginning of the experiments varied depending upon the nutrient in question (Table 2). A greater proportion of $\mathrm{NH}_{4}{ }^{+}$and DIP was remineralized in cores with sediments in the $3 \times$ treatment. The percentage of BSi remineralized decreased as the flux of 
A

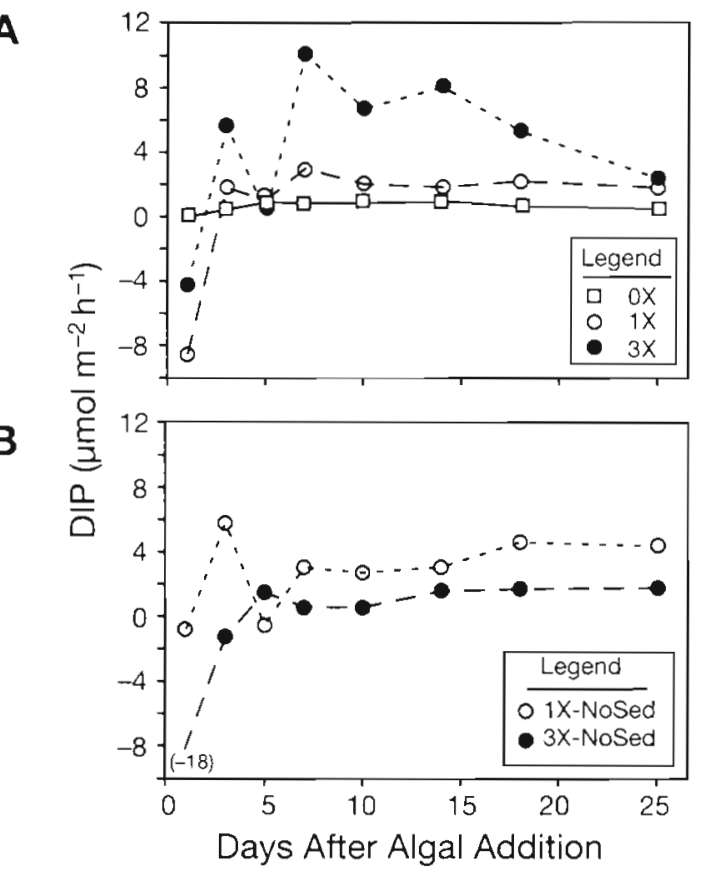

Fig. 8. Mean dissolved inorganic phosphate (DIP) flux for (A) cores containing sediment and (B) cores containing no sediment (NoSed). Symbols as in Fig. 5

algal material to the sediment increased in both cores with and without sediments. Comparison of the percentage of algal material remineralized in cores with intact sediments and in cores without sediments also varied with nutrient (Table 2). The percentage of BSi remineralized greatly decreased in cores with sediments as compared with cores without sediments. For $\mathrm{NH}_{4}{ }^{+}$and DIP, substantially more nutrient was remineralized in the $3 \times$ treatment with sediments.

\section{DISCUSSION}

Our laboratory simulation of the deposition of the spring diatom does offer direct experimental evidence that the flux of organic material is one of the most important factors controlling the rates and pathways of organic matter remineralization in sediments. An immediate response was observed to the simulated deposition of a spring diatom bloom in our microcosms: sediment-water fluxes of $\mathrm{DSi}_{1} \mathrm{NH}_{4}{ }^{+}$and DIP all substantially increased, large $\mathrm{NO}_{2}{ }^{-}+\mathrm{NO}_{3}{ }^{-}$fluxes were observed into the sediments, and sediment pore-water profiles were modified to some extent. The largest response was observed during the first to second week following the organic matter addition and the decreasing sediment-water fluxes following this peak may represent exhaustion of the more labile fraction of the detrital pool (Westrich \& Berner 1984). At the termi-
Table 2. Percentage of added algal material remineralized from cores with and without sediments (NoSed) calculated from trapezoidal integration of sediment-water fluxes over the $27 \mathrm{~d}$ following the single pulsed addition of organic matter. The flux from the control core was subtracted from the observed flux to determine percentage remineralized. BSi: biogenic silica; DIP: dissolved inorganic phosphate. Algal additions: added at $1 \times$ or $3 \times$ spring bloom proportions

\begin{tabular}{cccc|}
\hline Treatment & $\mathrm{BSi}$ & $\mathrm{NH}_{4}{ }^{+}$ & $\mathrm{DIP}$ \\
\hline $1 \times$-NoSed & $28 \%$ & $12 \%$ & $11 \%$ \\
$3 \times$-NoSed & $11 \%$ & $16 \%$ & $10 \%$ \\
$1 \times$ & $14 \%$ & $9.5 \%$ & $10 \%$ \\
$3 \times$ & $7.9 \%$ & $19 \%$ & $15 \%$ \\
\hline
\end{tabular}

nation of the experiment, almost 4 wk later, the cores which received the most organic matter $(3 \times)$ still had higher rates of sediment inorganic nitrogen metabolism than the basal rates observed in control microcosms (ANOVA with post-hoc least-significant difference comparison; $F=11.9, \mathrm{df}=5,54, \mathrm{p}=0.0001$ for $\mathrm{NO}_{2}{ }^{-}+\mathrm{NO}_{3}{ }^{-}$and $F=12.52, \mathrm{df}=5,54, \mathrm{p}=0.0001$ for $\mathrm{NH}_{4}{ }^{+}$.

Many workers have examined the effects of organic matter addition on sediment nutrient recycling processes, although most experiments have used relatively artificial substrates (Banta 1992, Caffrey et al. 1993) or freeze-dried organic material (Garber 1984, Kelly \& Nixon 1984, Banta 1992, van Raaphorst et al. 1992) to test the response of sediment nutrient recycling processes to organic matter addition. Previous studies have observed that the bulk of organic material can be degraded in as little as a few weeks (Graf et al. 1982, Garber 1984, Kelly \& Nixon 1984, Enoksson 1993). However, Garber (1984) has noted that after freezedrying up to $50 \%$ of the particulate organic material can be released as dissolved substances upon rehydration, which in turn dramatically increases the apparent efficiency of remineralization of organic matter in sediments. By contrast, in our experiment only 7.9 to $28 \%$ of added organic material was remineralized as the dissolved nutrients DSi, DIP, or $\mathrm{NH}_{4}{ }^{+}$during the $27 \mathrm{~d}$ addition experiment (Table 2). Our experiments were carried out at cooler temperatures $\left(4^{\circ} \mathrm{C}\right)$ than most previous studies $\left(10\right.$ to $\left.15^{\circ} \mathrm{C}\right)$, and remineralization can vary according to sediment type, temperature, the quality of the material, and as we have demonstrated, by the quantity of material added (Table 2 ). In addition, estimating the percentage remineralized by trapezoidal integration of the sediment-water fluxes of dissolved inorganic constituents over the course of the experiment may have underestimated the quantity of material remineralized because of release from dissolved organic compounds were not measured in this experiment. Enoksson (1993) observed that $50 \%$ of the 
sediment-water flux can be released as DON, suggesting that the release of DON and DOP may be a significant component of the release from sediments that was not measured in our experiments (Boynton et al. 1980, Hansen \& Blackburn 1991, 1992).

Initial nutrient fluxes into sediments were observed after addition of the organic material for some of the experimental treatments. The negative fluxes may represent algal uptake of nutrients following the addition. Numerous viable diatoms were observed in added algal material by light microscopy, and it is known that diatoms can remain intact and viable for long periods in darkness (Sicko-Goad et al. 1989) and are capable of dark DSi uptake and division based on stored energy reserves (Brzezinski \& Nelson 1989). Finally, the only reasonable explanation for negative DSi fluxes into the added algal material in the treatments without sediments (Fig. 5B) can be from uptake by viable diatoms. Viable diatoms at the sediment-water interface have been observed following the spring bloom in Århus Bight that contained considerable pools of intracellular $\mathrm{NO}_{3}{ }^{-}$and $\mathrm{NH}_{4}{ }^{+}$(Lomstein et al. 1990).

Although aerobic conditions were maintained throughout the duration of the experiments in the water column by bubbling air, the $3 \times$ treatments displayed symptoms of reduced oxygen concentrations at the sediment-water interface. Unfortunately technical problems prevented the measurement of dissolved oxygen $\left(\mathrm{O}_{2}\right)$ fluxes; however, the observed growth of Beggiatoa sp. bacteria on surficial sediments of the $3 \times$ treatment by the termination of the experiment would strongly support this conclusion. Although limited measurements demonstrated that the water column remained oxic, it seems likely that $\mathrm{O}_{2}$ consumption at and possibly above the sediment-water interface exceeded the delivery of $\mathrm{O}_{2}$ via diffusion, which could permit anaerobic conditions to persist at the sedimentwater interface. These reduced oxygen tensions would thus have a substantial effect on sediment-water fluxes. This is probably reflected here by the enhanced rates of $\mathrm{NH}_{4}{ }^{+}$release from sediments in the $3 \times$ treatment and the high DIP fluxes (Fig. 4). In addition, a larger percentage of $P$ was remineralized in the $3 \times$ treatment (Table 2) possibly from the increased mobilization of DIP from sediments during periods of low $\mathrm{O}_{2}$ from the reduction of ferric oxyhydroxides that usually bind DIP (Krom \& Berner 1980).

A greater proportion of anaerobic decomposition products, e.g. $\mathrm{NH}_{4}{ }^{+}$and DIP, were observed with an expansion of more reducing conditions resulting from the addition of organic matter. Significant debate has arisen as to the efficiency of organic matter remineralization under different pathways of sediment metabolism (e.g. aerobic versus anaerobic), with recent investigations arguing that fresh particulate organic matter degrades at similar rates under oxic and anoxic conditions (Henrichs \& Reeburgh 1987, Kristensen \& Blackburn 1987, Mackin \& Swider 1989, Hansen \& Blackburn 1991). However, the mineralization of dissolved organic molecules may be less efficient under anoxic conditions with higher rates of dissolved organic fluxes where anaerobic metabolism dominates (Henrichs \& Reeburgh 1987, Kristensen \& Blackburn 1987, Mackin \& Swider 1989, Hansen \& Blackburn 1991, 1992) such that the endproducts of aerobic metabolism $\left(\mathrm{CO}_{2}\right.$, denitrification greater) are different from those of anaerobic sediment metabolism (DOC, DON, $\mathrm{NH}_{4}{ }^{+}$).

The percentage of BSi remineralized decreased as more material was added $(3 x<1 \times)$ and the percentage of $\mathrm{BSi}$ remineralized decreased in cores with sediments compared to treatments without sediments (Table 2). Decreases in the percentage of material remineralized relative to an increased deposition of material on the sediment surface is consistent with model results of the accumulation rate of BSi in sediments (Pokras 1986, Conley \& Schelske 1989). Generally, the greater the flux of diatoms deposited to the sediment-water interface, the more diatoms preserved in the sediments, and the greater the concentration of DSi in porewaters as observed for the $3 \times$ treatment (Fig. 1A). The remineralization rate $(R)$ of BSi is largely driven by the concentration gradient between DSi concentrations at saturation $\left(\mathrm{DSi}_{\text {sat }}\right)$ with amorphous $\mathrm{BSi}$ and the observed DSi concentration ( $\mathrm{DSi}_{\text {obs }}$ ), e.g.

$$
R=k\left(\mathrm{DSi}_{\mathrm{sat}}-\mathrm{DSi}_{\mathrm{obs}}\right)
$$

where $k$ is the heterogeneous rate constant (Hurd 1983). Simply put, the greater the porewater DSi concentration, the lower the rate of BSi dissolution. Because of the steep exponential DSi concentration gradient often observed in sediments, most of the dissolution of BSi typically occurs in the upper $1 \mathrm{~cm}$ of the sediment column (Conley \& Schelske 1989, Martin et al. 1991).

Incubation of mesocosms without an intact benthic community and associated sediments can have a substantial effect on pelagic community structure (Pilson 1985, Doering et al. 1989). Incubation of sedimenting material in mesocosms without sediments can dramatically reduce P remineralization (Nixon et al. 1980), but can have a far less pronounced impact on the amount of $\mathrm{C}$ or $\mathrm{N}$ remineralized (Kelly \& Nixon 1984). In our experiments differences in remineralization of $\mathrm{P}$ in microcosms with and without sediments were most pronounced in the $3 \times$ treatment where sediment metabolism appeared to be influenced by anaerobic processes. The largest differences between cores incubated with and without intact sediments were observed for the remineralization of $\mathrm{BSi}$ with lower rates observed in microcosms with intact sediments 
(Table 2). Because of differences in porosity and diffusion, interstitial DSi concentrations should be greater in the decomposing algal material in cores with intact sediments as compared to those without sediments, and one would therefore expect the remineralization of BSi also to be less in cores with sediments versus cores without intact sediments. As described above, sediment porewater DSi concentrations retard the dissolution rate of $\mathrm{BSi}$.

Our experiments confirmed the importance of remineralization directly at the sediment-water interface. Sediment-water fluxes were enhanced in the $1 \times$ treatment over basal rates of sediment-metabolism in the control cores without necessarily modifying porewater distributions. In fact, measured sediment-water fluxes were generally greater than could be explained simply by Fickian diffusion from porewaters (Table 3 ). Part of the observed differences may lie in the fact that our sectioning was too coarse $(0.5 \mathrm{~cm}$ interval) such that micro-gradients could not be ascertained. Sediment-water fluxes calculated from porewater models provide estimates of metabolism within the sediment matrix, whereas measurements of sediment-water fluxes using core incubations include both aerobic metabolism at the sediment-water interface and a fraction of the anaerobic metabolism within the sediment matrix (Rowe \& McNichol 1991). In addition, the nutrients remineralized from the decomposing algal material at the sediment-water interface are limited by diffusion through the boundary layer, whereas diffusion is orders of magnitude lower for porewater nutrients diffusing through the sediment matrix (Berner

Table 3. Observed sediment-water fluxes measured by core incubation and sediment-water fluxes calculated from porewater nutrients. Calculated fluxes were made using a 2 point linear gradient between overlying water concentrations and concentrations in the 0.0 to $0.5 \mathrm{~cm}$ interval (Berner 1980) and temperature-corrected diffusion coefficients $\left(4^{\circ} \mathrm{C}\right)$ from Li \& Gregory (1974). Ox: control, no added algal material; $1 \times$ : algal material added in approximately spring bloom proportions; $3 \times$ : algal material at $3 \times$ spring bloom proportions; DSi: dissolved silicate; DIP: dissolved inorganic phosphate

\begin{tabular}{|lcccccc|}
\hline Treatment & \multicolumn{3}{c}{ Day 8} & \multicolumn{3}{c|}{ Day 27 } \\
& $0 \times$ & $1 \times$ & $3 \times$ & $0 \times$ & $1 \times$ & $3 \times$ \\
\hline DSi observed flux & 31.0 & 63.9 & 82.3 & 25.6 & 65.1 & 62.6 \\
DSi calculated flux & 68.2 & 67.4 & 176 & 61.0 & 87.7 & 72.1 \\
$\mathrm{NO}_{3}{ }^{-}$observed flux & 2.30 & 2.78 & -18.0 & 2.15 & 11.0 & 9.75 \\
$\mathrm{NO}_{3}{ }^{-}$calculated flux & 10.1 & -0.21 & - & 10.6 & 4.48 & -2.73 \\
$\mathrm{NH}_{4}{ }^{+}$observed flux & 2.61 & 40.5 & 154 & 0.65 & 11.3 & 24.2 \\
$\mathrm{NH}_{4}{ }^{+}$calculated flux & 14.4 & 28.7 & 122 & 1.75 & 2.27 & 23.6 \\
DIP observed flux & 0.81 & 3.00 & 10.1 & 0.44 & 1.78 & 2.32 \\
DIP calculated flux & 1.53 & 3.61 & 10.8 & 2.32 & 0.92 & 1.28 \\
- Could not be calculated because all $\mathrm{NO}_{3}{ }^{-}$was depleted from both \\
the water and from the sediment porewaters \\
\hline
\end{tabular}

1980). Finally, it should be noted that porewater models require an assumption of steady-state, which is clearly violated in this experimental manipulation.

\section{Nitrogen remineralization processes}

The effect of organic loading on sediment generally leads to increases in sediment $\mathrm{NH}_{4}{ }^{+}$remineralization with subsequent increases in $\mathrm{NH}_{4}{ }^{+}$sediment fluxes, and increases in $\mathrm{O}_{2}$ consumption (Kelly \& Nixon 1984, Caffrey et al. 1993). Any change in the balance of $\mathrm{NH}_{4}{ }^{+}$ availability, $\mathrm{O}_{2}$ availability, and the depth of anaerobic zones or the addition of organic substrates will alter the balance of nitrification, denitrification, and the dissimilatory reduction of $\mathrm{NO}_{3}{ }^{-}$to $\mathrm{NH}_{4}{ }^{+}$. All the above processes undoubtedly occurred in our experimental microcosms

Addition of fresh algal organic carbon to the sediment-water interface created a strong flux of $\mathrm{NO}_{2}^{-}+$ $\mathrm{NO}_{3}{ }^{-}$into the sediments from the water, perhaps due to the stimulation of denitrification, the reduction of $\mathrm{NO}_{3}{ }^{-}$to $\mathrm{N}_{2}$. Rönner (1985) estimated that $55 \%$ of nitrogen loading to the Baltic is denitrified on an annual basis, and increases in denitrification in response to elevated organic loadings have been reported for similar cold temperate sediments (Henriksen et al. 1981, Jensen et al. 1988, Hansen \& Blackburn 1991, 1992, Caffrey et al. 1993). Also, a significant increase in denitrification has been observed in sediments local to the present study sight as a result of the sedimenting annual spring bloom (Johnstone \& Koop unpubl. data). It is unclear from porewater profiles whether the decreased $\mathrm{NO}_{2}{ }^{-}+\mathrm{NO}_{3}$ levels are due to $\mathrm{O}_{2}$ limitation effecting nitrifiers within the sediment, or whether denitrification rates increased due to the supply of organic material and subsequently reduced the standing stock of $\mathrm{NO}_{2}^{-}+\mathrm{NO}_{3}{ }^{-}$in the upper sediment layers. Only a small efflux of $\mathrm{NO}_{2}^{-}+\mathrm{NO}_{3}^{-}$was observed from the sediments in the $1 \times$ cores but a significant flux into the sediment in the $3 \times$ cores. This may indicate that the rate of denitrification is in the same range as sediment nitrification rates in the $1 \times$ core, whereas the demand for $\mathrm{NO}_{2}^{-}$ $+\mathrm{NO}_{3}{ }^{-}$by denitrifiers in the $3 \times$ cores exceeds the supply from sediment nitrification such that water column sources provided a significant portion of $\mathrm{NO}_{3}{ }^{-}$consumed by denitrification in those treatments. It seems likely that consumption of water-column-derived $\mathrm{NO}_{3}{ }^{-}$ fuelled denitrification and that this accounted for the large $\mathrm{NO}_{2}{ }^{-}+\mathrm{NO}_{3}^{-}$fluxes into the sediments. 
Other $\mathrm{NO}_{3}{ }^{-}$consuming processes, however, may contribute to the large flux of $\mathrm{NO}_{2}{ }^{-}+\mathrm{NO}_{3}{ }^{-}$into the sediment. For example, the dissimilatory reduction of $\mathrm{NO}_{3}^{-}$ to $\mathrm{NH}_{4}{ }^{+}$has been shown to account for 20 to $60 \%$ of sediment $\mathrm{NO}_{3}{ }^{-}$consumption in shallow marine ecosystems (Sørenson 1987, Koike \& Sørenson 1988). Given the probable restriction in $\mathrm{O}_{2}$ distribution associated with the catabolism of the sedimented organic material, it is likely that conditions would be sufficiently reducing for this process to occur (Jensen et al 1990).

Nitrification, the oxidation of $\mathrm{NH}_{4}^{+}$to $\mathrm{NO}_{3}{ }^{-}$, is suggested by the $\mathrm{NO}_{2}{ }^{-}+\mathrm{NO}_{3}{ }^{-}$flux out of the sediments. Nedwell et al. (1983) has suggested that sediment nitrification prevents the release of $\mathrm{NH}_{4}{ }^{+}$from Baltic Sea sediments during winter and is supported by our results, which show that in control cores throughout the experiment and in the algal fed cores at the end of the experiment $\mathrm{NO}_{3}{ }^{-}$fluxes accounted for a large portion of the dissolved $\mathrm{N}$ flux. The subsurface peak in $\mathrm{NH}_{4}{ }^{+}$noted in porewaters in the $3 \times$ treatment at the end of the experiments with a near-surface decrease in concentration indicates that $\mathrm{NH}_{4}{ }^{+}$was probably converted to $\mathrm{NO}_{2}{ }^{-}+\mathrm{NO}_{3}{ }^{-}$in surface sediments. Apparently although $\mathrm{O}_{2}$ penetration was limited during this period, sufficient $\mathrm{O}_{2}$ penetration must have occurred to account for the $\mathrm{NO}_{2}{ }^{-}+\mathrm{NO}_{3}{ }^{-}$present in porewaters of the upper sediment layer $(0.5 \mathrm{~cm})$ at the termination of the experiment, which in turn likely limited the rate of nitrification (Caffrey et al. 1993). Jensen et al. (1990) suggest that nitrification temporarily ceases after rapid sedimentation events such that nutrient-rich bottom water temporarily becomes the chief $\mathrm{NO}_{3}{ }^{-}$source for denitrification, such that denitrification is no longer coupled to nitrification (Jenkins \& Kemp 1984).

\section{Extrapolation to the Baltic Sea}

The response of sediments to increases in the deposition rate of organic matter may vary depending upon a variety of factors including differences in sediment type (Conley \& Schelske 1989, van Raaphorst et al. 1992), water depth and the related difference in the physical forcings such as resuspension (Floderus \& Håkanson 1989), the abundance of benthic macrofauna (Aller 1982), or the prevailing chemistry of the water as, for example, in the anoxic basins of the Baltic Sea (Jonsson et al. 1990). Although sediments in accumulation bottoms have a greater adsorption capacity for DIP compared to the generally non-depositional oxidized shallower sediments, the extent of the area of relatively shallow sediments in the Baltic Sea makes them capable of acting as a major sink for P (Carman \& Wulff 1989) and they may react somewhat differently from the sediments used in this study.
Our laboratory simulation of the deposition of the spring diatom bloom does offer direct experimental evidence that the magnitude of recent organic matter deposition can exert a major influence on sedimentwater exchange rates especially given the relatively short period over which the bulk of this material is delivered. The addition of algal material in a proportion similar to what is deposited during an average spring bloom $(1 \times)$ had a stimulatory effect on sediment-water fluxes and only a minor effect on porewater nutrient concentrations. However, our $3 \times$ treatment, which mimics increased deposition with increased eutrophication, exhibited a substantial and lasting effect on sediment-water fluxes and porewater nutrient concentrations. Modification of porewater nutrient concentrations following the deposition of diatom blooms have been only occasionally observed in nature (Nedwell et al. 1983, Jensen et al. 1990), although observed increases can be confounded by increases in the temperature-dependent microbial decomposition of organic matter in shallow water systems. The major changes observed required only a small increase in organic matter deposition rates to effect a rather dramatic change in fluxes.

It is widely believed that anthropogenic inputs of nutrients to the Baltic Sea will continue to rise with projected increases in blooms and increases in algal sedimentation rates expected (Wulff \& Niemi 1992, Sandén \& Rahm 1993). Dramatic differences were observed in sediment-water fluxes and porewater nutrient concentrations with addition of organic matter to sediments and our results suggest that additional increases in the deposition of organic matter to sediments with eutrophication may have an undesirable effect on nutrient recycling processes. The decrease in the rate of BSi remineralization with increased deposition in our experiments may be responsible for the long-term declines in DSi concentrations reported for the Baltic Sea (Sandén et al. 1991) which may lead to floristic changes in phytoplankton communities as well as the potential for an increased frequency of toxic algal blooms (Conley et al. 1993). Although the deposition rates similar to a typical spring diatom bloom as simulated in this study did not have long-term effects on nutrient recycling processes, we demonstrated that increases above the present level of deposition may have a significant impact on nutrient biogeochemical cycles in the Baltic Sea.

Acknowledgements. We thank Frednk Wulff and Lars Rahm for help in sponsoring this research project and their assistance along the way. We also thank Nicki Bagger, Jan-Erik Hagerroth and Olle Meier for assistance in the field, Karin Bjorkman, Florence Eberhardt and Lisa Rosman for laboratory assistance, and the staff and personnel at the Askö Labo- 
ratory where this research was accomplished. We thank Viveka Enoksson, Samantha B. Joye, Peter Sampou, Fredrik Wulff and 3 anonymous reviewers tor providing valuable comments on this manuscript. This research project was completed while D.J.C. was a visiting scientist in the Department of Systems Ecology, Stockholm University through an NFR grant to F. Wulff. This is Contribution No. 2650 of UMCEES and a contribution of the Department of Systems Ecology. Stockholm University.

\section{LITERATURE CITED}

Aller RC (1982) The effects of macrobenthos on chemical properties of marine sediment and overlying water. In: McCall PL, Tevesz MJ (eds) Animal-sediment relations: the biogenic alteration of sediments. Plenum Press, New York, p 53-102

Aspila KI, Agemian H, Chau ASY (1976) A semi-automated method for the determination of inorganic, organic and total phosphorus in sediments. Analyst 101:187-197

Banta GT (1992) Decomposition and nitrogen cycling in coastal marine sediments - controls by temperature, organic matter inputs, and benthic macrofauna. PhD dissertation, Boston University

Berner RA (1980) Early diagenesis: a theoretical approach. Princeton University Press, Princeton

Blomqvist S, Abrahamsson B (1985) An improved Kajak-type gravity core sampler for soft bottom sediments. Schweiz Z Hydrol 47:81-84

Boynton WR, Kemp WM, Osborne CG (1980) Nutrient fluxes across the sediment-water interface in the turbid zone of a coastal plain estuary. In: Kennedy VS (ed) Estuarine perspectives. Academic Press, New York, p 93-109

Brzezinski MA (1985) The Si:C:N ratio of marine diatoms: interspecific variability and the effect of some environmental variables. J Phycol 21:347-357

Brzezinski MA, Nelson DM (1989) Seasonal changes in the silicon cycle within a Gulf Stream warm-core ring. Deep Sea Res 36:1009-1030

Caffrey JM, Sloth NP, Kasper HF, Blackburn TH (1993) Effect of organic loading on nitrification and denitrification in a marine sediment microcosm. FEMS Microbiol Ecol 12:159-167

Carman R, Wulff R (1989) Adsorption capacity of phosphorus in Baltic Sea sediments. Estuar coast Shelf Sci 29:447-456

Cederwall H, Elmgren R (1980) Biomass increase of benthic macrofauna demonstrates eutrophication of the Baltic Sea. Ophelia Suppl 1:287-304

Conley DJ, Schelske CL (1989) Processes controlling the benthic regeneration and sedimentary accumulation of biogenic silica in Lake Michigan. Arch Hydrobiol 116: $23-43$

Conley DJ, Schelske CL, Stoermer EF (1993) Modification of the biogeochemical cycle of silica with eutrophication. Mar Ecol Prog Ser 101:179-192

DeMaster DJ (1981) The supply and accumulation of silica in the marine environment. Geochim Cosmochim Acta 45:1715-1732

Doering $\mathrm{PH}$, Oviatt CA, Beatty LL, Banzon VF, Rice R, Kelly SP, Sullivan BK. Frithsen JB (1989) Structure and function in a model coastal ecosystem: silicon, the benthos and eutrophication. Mar Ecol Prog Ser 52:287-299

Elmgren R (1984) Trophic dynamics in the enclosed, brackish Baltic Sea. Rapp P-v Reun Cons int Explor Mer 183: 152-169

Elmgren R (1989) Man's impact on the ecosystem of the Baltic
Sea: energy flows today and at the turn of the century Ambio 18:326-332

Enoksson V (1993) Nutrient recycling by coastal sediments: effects of added algal material. Mar Ecol Prog Ser 92: $245-254$

Floderus S, Håkanson L (1989) Resuspension, ephemeral mud blankets and nitrogen cycling in Laholmsbukten, south east Kattegat. Hydrobiologia 176/177:61-75

Garber JH (1984) Laboratory study of nitrogen and phosphorus remineralization during decomposition of coastal plankton and seston. Estuar coast Shelf Sci 18:685-702

Gardner WS, Nalepa TF, Frez WA, Chichocki EA, Landrum PF (1985) Seasonal patterns in lipid content of Lake Michigan macroinvertebrates. Can J Fish Aquat Sci 42 $1827-1832$

Graf G (1987) Benthic energy flow during a simulated autumn bloom sedimentation. Mar Ecol Prog Ser 39:23-29

Graf G. Bengtsson W, Diesner U, Schulz R, Theede H (1982) Benthic response to sedimentation of a spring phytoplankton bloom: process and budget. Mar Biol 67:201-208

Graf G, Bengtsson W, Faubel L, Meyer-Reil L, Schulz R,

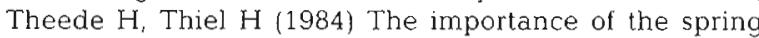
phytoplankton bloom for the benthic system of Kiel Bight Rapp P-v Reun Cons int Expor Mer 183:136-143

Hansen LS, Blackburn TH (1991) Aerobic and anaerobic mineralization of organic material in marine sediment microcosms. Mar Ecol Prog Ser 75:283-291

Hansen LS, Blackburn TH (1992) Effect of algal bloom deposition on sediment respiration and fluxes. Mar Biol 112 $147-152$

Henrichs SM, Reeburgh WS (1987) Anaerobic mineralization of marine sediment organic matter: rates and the role of anaerobic processes in the oceanic carbon economy. Geomicrobiol J 5:191-237

Henrikson K, Hansen JI, Blackburn TH (1981) Rates of nitrification, distribution of nitrifying bacteria, and nitrate fluxes in different types of sediments from Danish waters. Mar Biol 61:299-304

Hurd DC (1983) Physical and chemical properties of siliceous skeletons. In: Aston SR (ed) Silicon geochemistry and biogeochemistry. Academic Press, New York, p 187-244

Jenkins MC. Kemp WM (1984) The coupling of nitrification and denitrification in two estuarine sediments. Limnol Oceanogr 29:609-619

Jensen MH, Andersen TK, Sorensen J (1988) Denitrification in coastal bay sediment: regional and seasonal variation in Aarhus Bight, Denmark. Mar Ecol Prog Ser 48:155-162

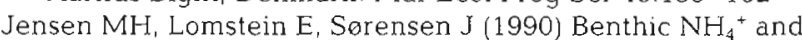
$\mathrm{NO}_{3}{ }^{-}$flux following sedimentation of a spring phytoplankton bloom in Aarhus Bight, Denmark. Mar Ecol Prog Ser 61:87-96

Jonsson P, Carman R, Wulff F (1990) Laminated sediments in the Baltic - a tool for evaluating nutrient mass balances. Ambio 19:152-158

Kelly JR, Nixon SW (1984) Experimental studies of the effect of organic deposition on the metabolism of a coastal marine bottom community. Mar Ecol Prog Ser 17:157-169

Koike I, Sorensen J (1988) Nitrate reduction and denitrification in marine sediments. In: Blackburn TH, Serensen J (eds) Nitrogen cycling in coastal marine environments. Wiley, New York, p 251-273

Koop K, Boynton WR, Wulff F, Carman R (1990) Sedimentwater oxygen and nutrient exchanges along a depth gradient in the Baltic Sea. Mar Ecol Prog Ser 63:65-77

Koroleff F (1976) Determination of total phosphorus. In Grasshoff $K$ (ed) Methods of seawater analysis. Verlag Chemie, Weinheim, p 123-125 
Kristensen E, Blackburn TH (1987) The fate of organic carbon and nitrogen in experimental marine sediment systems: influence of bioturbation and anoxia. $\mathrm{J}$ mar Res 45: 231-257

Krom MD, Berner RA (1980) The diagenesis of phosphorus in a nearshore marine sediment. Geochim Cosmochim Acta 45:207-216

Larsson U, Elmgren R, Wulff F (1985) Eutrophication and the Baltic Sea: causes and consequences. Ambio 14:9-14

Larsson U, Hobro R, Wulff F (1986) Dynamics of a phytoplankton spring bloom in a coastal area of the Northern Baltic proper. Contributions from the Asko Laboratory, Stockholm University, Stockholm, No 30

Li YH, Gregory S (1974) Diffusion of ions in sea water and in deep-sea sediments. Geochim Cosmochim Acta 38: $703-714$

Lignell R, Heiskanen AS, Kuosa H, Gundersen K, KuuppoLeinikki P. Pajuniemi R, Uitto A (1993) Fate of a phytoplankton spring bloom: sedimentation and carbon flow in the planktonic food web in the northern Baltic. Mar Ecol Prog Ser 94:239-252

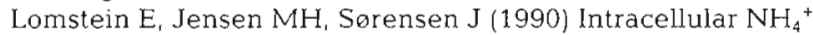
and $\mathrm{NO}_{3}{ }^{-}$pools associated with deposited phytoplankton in a marine sediment (Aarhus Bight, Denmark). Mar Ecol Prog Ser 61:97-105

Mackin JE, Swider KT (1989) Organic matter decomposition pathway and oxygen consumption in coastal marine sediments. J mar Res 47:681-716

Martin WR, Bender M, Leinen M, Orchardo J (1991) Benthic organic carbon degradation and biogenic silica dissolution in the central equatorial Pacific. Deep Sea Res 38: $1481-1516$

Nedwell DB, Hall SE, Andersson A, Hagstrom Â, Linstrom EB (1983) Seasonal changes in the distribution and exchange of inorganic nitrogen between sediment and water in the Northern Baltic (Gulf of Bothnia). Estuar coast Shelf Sci 17:169-179

Nixon SW, Kelly JR, Furnas BN, Oviatt CA, Hale SS (1980) Phosphorus regeneration and the metabolism of coastal marine bottom communities. In: Tenore KR, Coull BC (eds) Marine benthic dynamics. University of South Carolina Press, Columbia, p 219-242

Paasche E (1980) Silicon content of five marine plankton diatom species measured with a rapid filter method. Limnol Oceanogr 25:474-480

Parsons TR, Maita Y, Lalli CM (1984) A manual of chemical and biological methods for seawater analysis. Pergamon Press, London, $173 \mathrm{p}$

Pilson MEQ (1985) Annual cycles of nutrients and chlorophyll in Narragansett Bay, Rhode Island. J mar Res $43: 849-873$

This article was submitted to the editor
Pokras EM (1986) Preservation of fossil diatoms in Atlantic sediment cores: control by supply rate. Deep Sea Res 33:893-902

Rowe GT, McNichol AP (1991) Carbon cycling in coastal sediments: estimating remineralization in Buzzards Bay, Massachusetts. Geochim Cosmochim Acta 55:2989-2991

Rönner U (1985) Nitrogen transformation in the Baltic proper: denitrification counteracts eutrophication. Ambio 14: $134-138$

Rydberg L, Edler L, Floderus S, Graneli W (1990) Interaction between supply of nutrients, primary production, sedimentation and oxygen consumption in SE Kattegat. Ambio 19:134-141

Sandén P, Rahm L (1993) Nutrient trends in the Baltic Sea. Environmetrics 4:75-103

Sandén P, Rahm L, Wulff F (1991) Non-parametric trend test of Baltic Sea data. Environmetrics 2:263-278

Sicko-Goad L, Stoermer EF, Kociolek JP (1989) Diatom resting cell rejuvenation and formation: time course, species records and distribution. J Plankton Res 1 1:375-389

Smetacek V (1985) The annual cycle of Kiel Bight plankton: a long-term analysis. Estuaries 8:145-157

Smetacek V, Passow U (1989) Spring bloom initiation and Sverdrup's critical-depth model. Limnol Oceanogr 35 : $228-234$

Smetacek V, von Brockel K, Zeitschel B, Zenk W (1978) Sedimentation of particulate matter during a phytoplankton spring bloom in relation to the hydrographical regime. Mar Biol 47:211-226

Srrensen J (1987) Nitrate reduction in marine sediment pathways and interactions with iron and sulfur cycling. Geomicrobiol J 5:401-421

Stigebrandt A, Wulff $F$ (1987) A model for the dynamics of nutrients and oxygen in the Baltuc proper. $J$ mar Res 45:729-759

van Raaphorst $W$, Kloosterhuis HT, Berghuis EM, Gieles AJM, Malschaert JFP, van Noort GJ (1992) Nitrogen cycling in two types of sediments of the southern North Sea (Frisian Front, Broad Fourteens): field data and mesocosm results. Neth J Sea Res 28:293-316

Westrich JT, Berner RA (1984) The role of sedimentary organic matter in bacterial sulfate reduction: the $\mathrm{G}$ model tested. Limnol Oceanogr 29:236-249

Wulff F, Ertebjerg G, Nicolaus G, Niemi $\AA$, Ciszewski P Schulz $S$, Kaiser $W$ (1986) The changing pelagic ecosystem of the Baltic Sea. Ophelia Suppl 4:299-319

Wulff F, Niemi $\AA$ (1992) Priorities for the restoration of the Baltic Sea - a scientific perspective Ambio 21:193-195

Wulff F, Stigebrandt A, Rahm L (1990) Nutrient dynamics of the Baltic Sea. Ambio 19:126-133

Manuscript first received: February 8, 1994

Revised version accepted: February 14, 1995 